\title{
Norovirus detection in wastewater and its correlation with human gastroenteritis: a systematic review and meta-analysis
}

\author{
Yue Huang ${ }^{1,2} \cdot$ Nan Zhou $^{1,2}$. Shihan Zhang ${ }^{1,2} \cdot$ Youqin $\mathrm{Yi}^{1,2} \cdot$ Ying Han $^{1,2} \cdot$ Minqi Liu $^{1,2} \cdot$ Yue Han ${ }^{1,2} \cdot$ Naiyang Shi $^{1,2}$. \\ Liuqing Yang ${ }^{1,2} \cdot$ Qiang Wang ${ }^{1,2} \cdot$ Tingting Cui ${ }^{1,2} \cdot$ Hui Jin $^{1,2}(\mathbb{D}$
}

Received: 24 September 2021 / Accepted: 14 December 2021 / Published online: 19 January 2022

(c) The Author(s), under exclusive licence to Springer-Verlag GmbH Germany, part of Springer Nature 2022

\begin{abstract}
Norovirus (NoV) is a major cause of sporadic cases and outbreaks of acute gastroenteritis (AGE), thereby imposing threat to health globally. It is unclear how quantitation of wastewater NoV reflects the incidence of human AGE infections; therefore, we conducted this systematic review and meta-analysis of published NoV wastewater surveillance studies. A literature search was performed, and all studies on NoV wastewater surveillance were identified. Quantitative results were evaluated. The results showed that the overall detection rate of NoV in wastewater was $82.10 \%$ (95\% confidence interval [CI]: 74.22$89.92 \%)$; NoV concentration was statistically significant in terms of season $(P<0.001)$, with higher concentration in spring and winter. There were positive correlations between NoV GII concentration in wastewater and GII AGE cases $\left(r_{s}=0.51\right.$, 95\% CI: $\left.0.18-0.74, I^{2}=0 \%\right)$, total AGE cases $\left(r_{s}=0.40,95 \%\right.$ CI: $\left.0.15-0.61, I^{2}=23 \%\right)$ and NoV outbreaks $\left(r_{s}=0.47,95 \%\right.$ CI: $\left.0.30-0.62, I^{2}=0 \%\right)$. Results of cross-correlation analysis of partial data indicated that variations in GII concentration were consistent with or ahead of those in the number of AGE cases. The diversity of NoV genotypes in wastewater was elucidated, and the dominant strains in wastewater showed a consistent temporal distribution with those responsible for human AGE. Our study demonstrated the potential association of NoV detected in wastewater with AGE infections, and further studies are needed to confirm this conclusion.
\end{abstract}

Keywords Wastewater surveillance $\cdot$ Norovirus $\cdot$ Human gastroenteritis $\cdot$ Detection $\cdot$ Meta-analysis $\cdot$ Systematic review

\section{Introduction}

Norovirus (NoV) is the leading cause of sporadic cases and outbreaks of acute gastroenteritis (AGE) in all age groups, causing more than 699 million infections and approximately 212,000 deaths worldwide each year (Lopman et al. 2016; Netzler et al. 2019). NoVs are non-enveloped viruses of the Caliciviridae family that have a single-stranded RNA genome of approximately $7.5 \mathrm{~kb}$ in length which contain

Responsible Editor: Lotfi Aleya

Hui Jin

jinhuihld@seu.edu.cn

1 Department of Epidemiology and Health Statistics, School of Public Health, Southeast University, Nanjing 210009, China

2 Key Laboratory of Environmental Medicine Engineering, Ministry of Education, School of Public Health, Southeast University, Nanjing 210009, China three open reading frames (ORFs): ORF1 encodes a polyprotein, ORF2 encodes the major structural protein (VP1), and ORF3 encodes the minor structural protein (VP2). Based on the complete capsid amino acid sequences, NoVs were divided into 10 genogroups (GI-GX) and a further subdivision into 49 genotypes (Chhabra et al. 2019). GI, GII, and GIV are reported to infect humans. Due to the genetic diversity and evolutionary complexity, there were at least six NoV mutant strains known to cause worldwide pandemics in the last 20 years (Nordgren and Svensson 2019).

Continuous monitoring for $\mathrm{NoV}$ is imperative. Several inter-regional NoV surveillance networks, including NoroNet (https://www.rivm.nl/en/noronet) and CaliciNet (https:// www.cdc.gov/norovirus/reporting/calicinet/), have been developed worldwide. NoroNet collects molecular epidemiological data on NoV infections from 19 countries in Europe, Asia, and Australia (Green 2018); whereas, CaliciNet monitors NoV outbreaks mainly in the USA as well as in parts of China (Cannon et al. 2017; Jin et al. 2020). Clinical surveillance relies primarily on clinical samples from patients 
at healthcare facilities, which can barely focus on people with mild infections and asymptomatic infections. Evidence favors the notion that NoV may cause higher rates of asymptomatic acute gastroenteritis infections within household and community (de Wit et al. 2001; Quee et al. 2020; Teunis et al. 2015).

Wastewater surveillance/wastewater-based epidemiology (WBE) is another ideal approach for monitoring viruses prevalence and to date has been applied to screen for a wide range of water-borne and non-water-borne viruses (O'Brien and Xagoraraki 2019). It bridges the gap of individual clinical testing by providing an unbiased estimate of disease prevalence in the whole population. Poliovirus wastewater surveillance as a complementary method to the Global Polio Eradication Initiative has been included in the World Health Organization (WHO) guidelines for environmental poliovirus surveillance (Sein 2013). During the COVID-19 pandemic, detection technology and method for wastewater surveillance were conducted globally as SARS-CoV-2 screening approach within communities. Besides early warnings for localized outbreaks (Chavarria-Miró et al. 2021; Medema et al. 2020), several studies further found the consistent trends in the temporal distribution of SARS-CoV-2 concentration in raw sewage and local cases (Daughton 2020; Peccia et al. 2020; Weidhaas et al. 2021; Wurtzer et al. 2020).

Host-specific NoV sheds through the feces of infected individuals_-including those with severe, mild, and asymptomatic infections-and enters wastewater, following which it can remain at high concentration in the water (Ngazoa et al. 2008). NoV cannot replicate in nonhost organisms in the environmental media, which means that the measured NoV concentration of raw wastewater can reflect AGE infection in the local population, theoretically. However, standard protocols and procedures for NoV detection have not yet been established in the field of viral wastewater surveillance, and it is unclear how NoV detection in wastewater quantitatively reflects the incidence of human AGE infections. On the basis of the above evidence, we performed a systematic review and meta-analysis of past NoV wastewater surveillance studies to explore and estimate the correlation between NoV occurrence in wastewater and AGE in the population.

\section{Materials and methods}

\section{Search strategy}

A literature search was conducted in PubMed and Embase databases from inception to August 13, 2021. The search keywords were as follows: ("sewage" OR "wastewater") AND ("norovirus" OR "Norwalk-like virus" OR "small round structured viruses"). Hand searching and screening of the reference list was also conducted. The literature was screened by reading the title, and after eliminating irrelevant literature, study eligibility was further assessed by reading the abstract and full text. Screening abstracts, articles that meet the following criteria are included first:

(a) reported outcome indicators reflecting virus detection in wastewater, such as NoV detection rate, viral RNA concentration, and temporal distribution by genotype;

(b) continuous sampling for at least 3 months.

Then reading the full text, the final selection of eligible articles was based on the following exclusion criteria:

(a) studies that did not classify NoV genogroups;

(b) case reports or case series of viral gastroenteritis outbreaks;

(c) studies that did not report detailed data;

(d) wastewater type was not raw wastewater (raw wastewater was defined as influent sewage before or after primary screening and settling from the municipal wastewater treatment plant);

(e) full text not available; or

(f) reported duplicate data.

The literature was screened, selected, and cross-checked by two researchers independently. Disagreements, if any, were resolved through discussion or consultation with a third researcher.

\section{Data extraction and assessment}

Data for the following variables were extracted from all eligible articles: (a) basic information: title of study, first author, year of publication, and country or region; (b) sampling and processing information: sample size, collection season or month, virus concentration method, and polymerase chain reaction (PCR) assay; (c) primary outcome indicators: NoV detection rate, viral concentration, and genotyping information for wastewater detection; (d) other outcome indicators, if available: content reflecting population prevalence, i.e., number of GI or GII AGE cases, number of NoV outbreak, or number of total AGE cases; the limit of detection (LOD). GetData Graph Digitizer, version 2.25 , was used to extract the required data from the images.

Each included study was independently reviewed and assessed by two researchers according to the AHRQ crosssectional study assessment scale. We modified some of the items to accommodate the included articles (Supplementary Sect. 1). 


\section{Statistical analysis}

During data processing, missing data on concentration that were below LOD were replaced with a value equal to the peer-reviewed LOD divided by square root of 2 . The units of NoV RNA concentration were unified as $\log 10$ genome copies per liter (lg GC/L), to make the data close to the normal distribution.

IBM SPSS Statistics 25.0 and R 4.0.3 software programs were used for data analyses in this study. NoV detection rate was subjected to Freeman-Tukey double arcsine transformation. One-way analysis of variation (ANOVA) was used to assess the statistical significance of NoV concentration. In addition, Spearman's correlation coefficients in each study that provided raw data was calculated. To estimate the standard errors, coefficients were converted to Fisher's $Z$ values. Meta-analysis and meta-regression were performed using the meta package in R. Heterogeneity among studies was determined using the $\mathrm{Q}$ test statistic and $I^{2}$. For $P<0.05$ or $I^{2}>50 \%$, heterogeneity was considered to exist and a random-effects model was used; otherwise, a fixed-effects model was used.

\section{Results}

\section{Search results}

A total of 8688 studies were identified following the database search. After removing duplicates, 5719 studies remained for screening. By screening the title and abstract and after excluding irrelevant studies, 164 needed to be screened by reading the full text. Finally, 46 were selected for the analysis (Fig. 1).

\section{Study characteristics and quality assessment}

The characteristics and basic information of 46 included studies are presented in Table 1. According to WHO mortality stratum (World Health Organization 2003a, b), there were 29 studies from developed countries, 13 from lowmortality developing countries, and 4 from high-mortality developing countries. Most studies $(n=28)$ were sampled for $\leq 1$ year, and only 4 studies were sampled for more than three years. Different methods were used for assessing the virus concentration, including adsorption-elution $(n=16)$,
Fig. 1 Flow diagram of included studies and the selection process
Records identified through database
searching

$(\mathrm{n}=8688)$
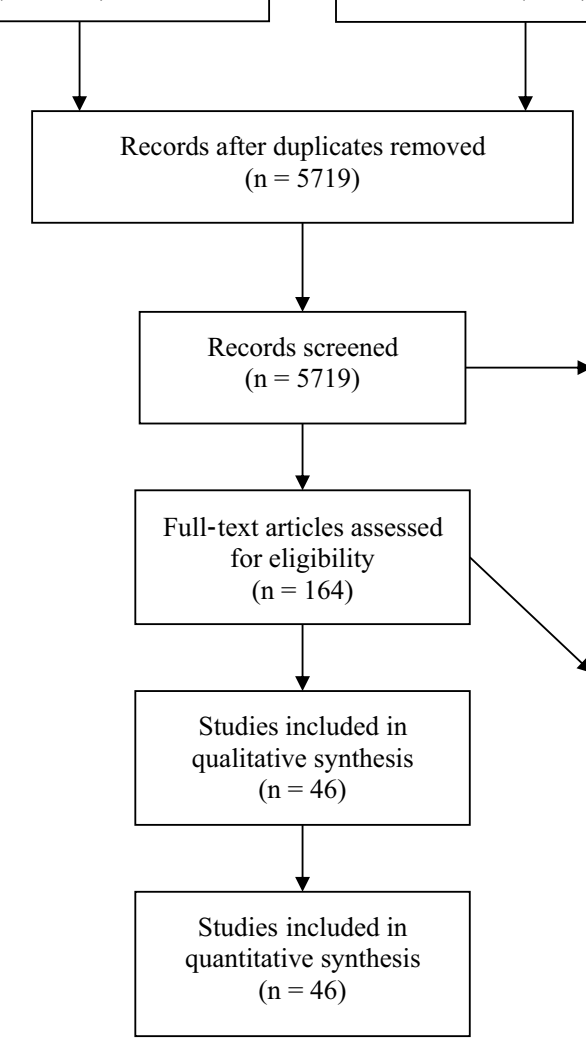

Records excluded $(\mathrm{n}=5555)$
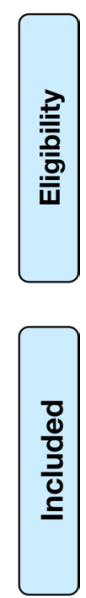

Full-text articles excluded, with reasons $(\mathrm{n}=118)$ :

8 did not classify NoV genogroups

34 viral gastroenteritis outbreaks

39 no raw data

29 not raw sewage

6 cannot find full text

2 duplicate data 


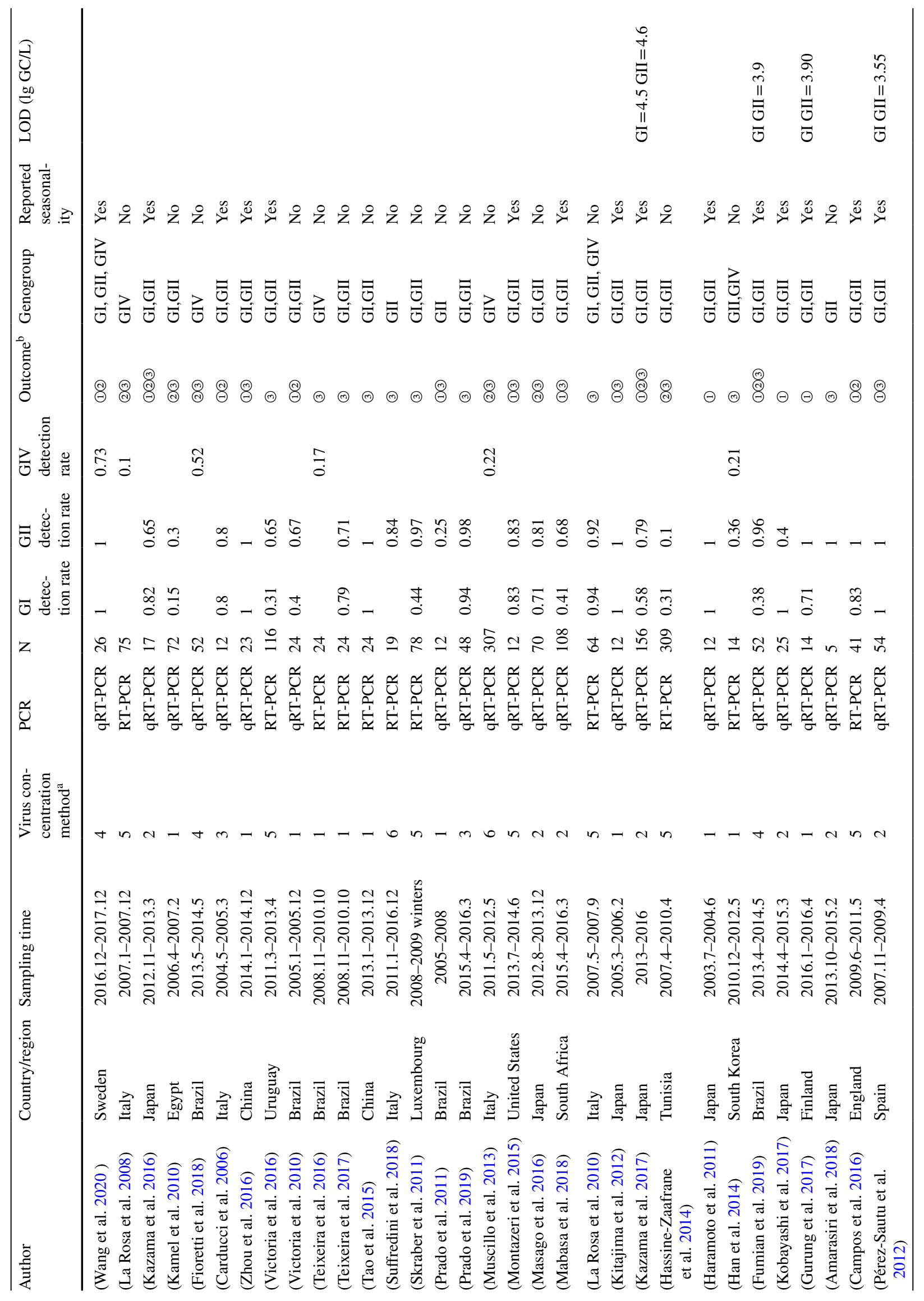




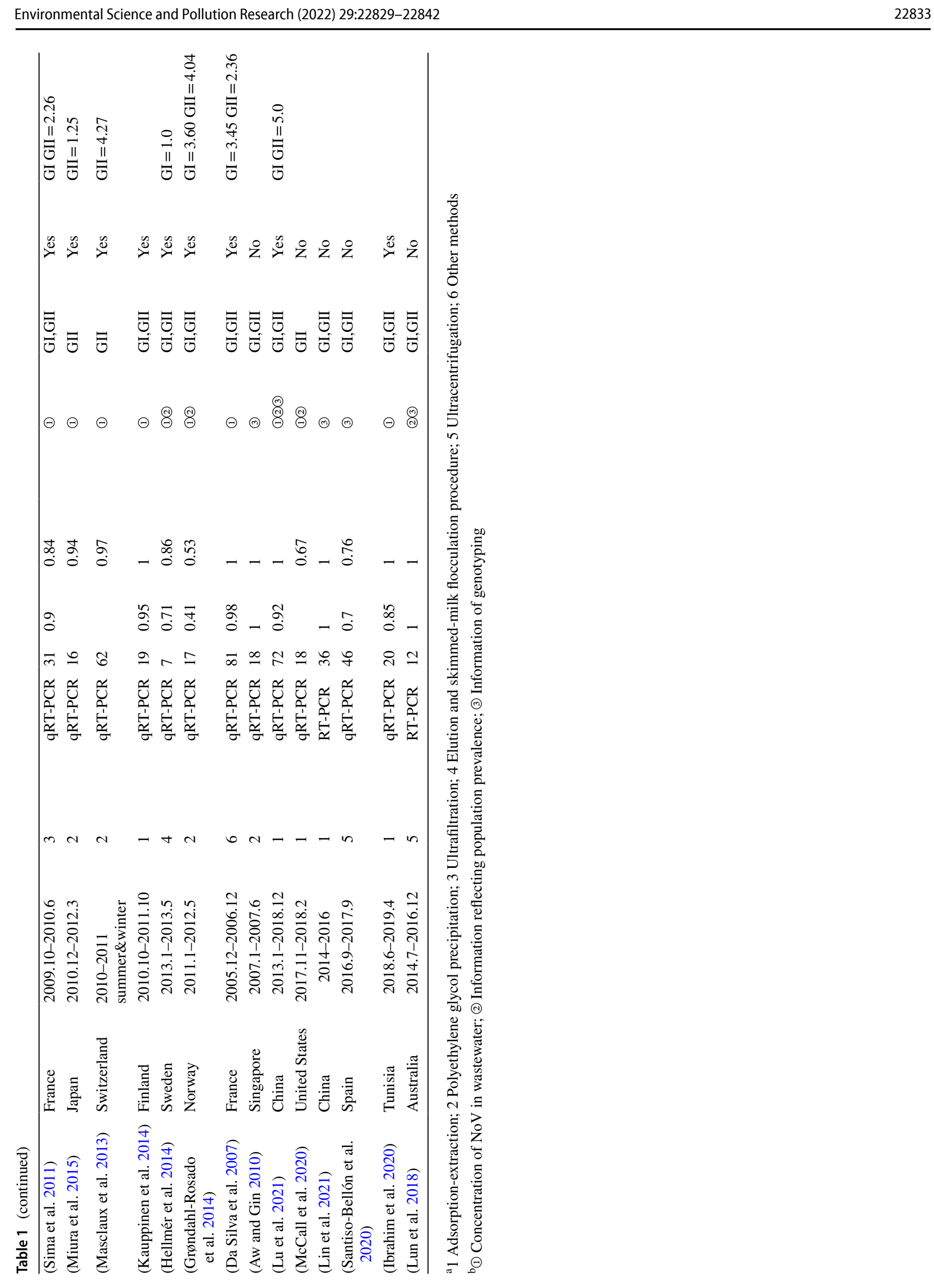

琞 Springer 
polyethylene glycol precipitation $(n=11)$, ultracentrifugation $(n=9)$, elution and skimmed-milk flocculation procedure $(n=4)$, ultrafiltration $(n=3)$, and others $(n=3)$. GII was the most frequently detected genogroup $(n=42)$, with only few detected for GIV $(n=7)$. Eighteen studies collected both wastewater samples and population gastrointestinal infection data, but only a part of them provided detailed data for calculating correlation coefficients, and the remainder described phylogenetic results for positive samples.

On assessing the quality of each study, seven articles were evaluated as having high quality, 32 as moderate, and seven as low, with an average quality score of $6.30 \pm 1.93$ (Supplementary Table S1). Regarding the assessment and adjustment of inhibition and recovery rates, approximately two-thirds of the studies did not report these rates.

\section{Meta-regression of NoV detection rates}

A meta-analysis was performed on the NoV detection rate reported in 46 studies, and the overall detection rate was 82.10\% (95\% confidence interval [CI]: 74.22-89.92\%) (Supplementary Table S2). NoV genogroup, country mortality, PCR method, sampling duration, and virus concentration quantification method were used as variables for the univariate meta-regression analysis of NoV detection rates (Supplementary Table S3). The results showed that NoV genogroup and country mortality significantly affected the heterogeneity of the meta-analysis results. When including both NoV genogroup and country mortality into the multifactor regression model, the $R^{2}$ was $52.81 \%$, which suggests that NoV genogroup and country mortality can explain part of the heterogeneity in detection rates. Greater detection rates in NoV GI $(81.90 \%, 95 \%$ CI: $71.26-90.70 \%)$ and GII (88.04\%, 95\% CI: $77.23-96.05 \%)$ and countries with higher development levels and lower overall mortality (developed countries (87.33\%, 95\% CI: 79.22-93.87\%), low-mortality developing countries (78.01\%, 95\% CI: 63.77-89.68\%)) were observed compared to GIV (30.89\%, 95\% CI: $15.45-48.73 \%)$ and high-mortality developing countries (47.08\%, 95\% CI: $27.85-66.75 \%)$.

\section{Seasonal differences in NoV concentration}

Twenty-six studies reported data for NoV concentration in wastewater in different seasons, 22 studies monitored GI and GII, and four studies monitored only GII. NoV GIV was not included in the quantitative analysis owing to insufficient data. In total, the GI concentration in wastewater was 5.34 (95\% CI: 5.18-5.49) $\mathrm{lg}$ GC/L and the GII concentration was 5.74 (95\% CI: 5.62-5.87) lg GC/L. ANOVA results showed that the concentrations of GI and GII were statistically significant in terms of season $(P<0.001)$, with higher concentration observed in spring and winter than in summer and autumn (Fig. 2, Supplementary Table S4).
Fig. 2 Boxplot of seasonal variation of NoV GI and GII concentrations in wastewater

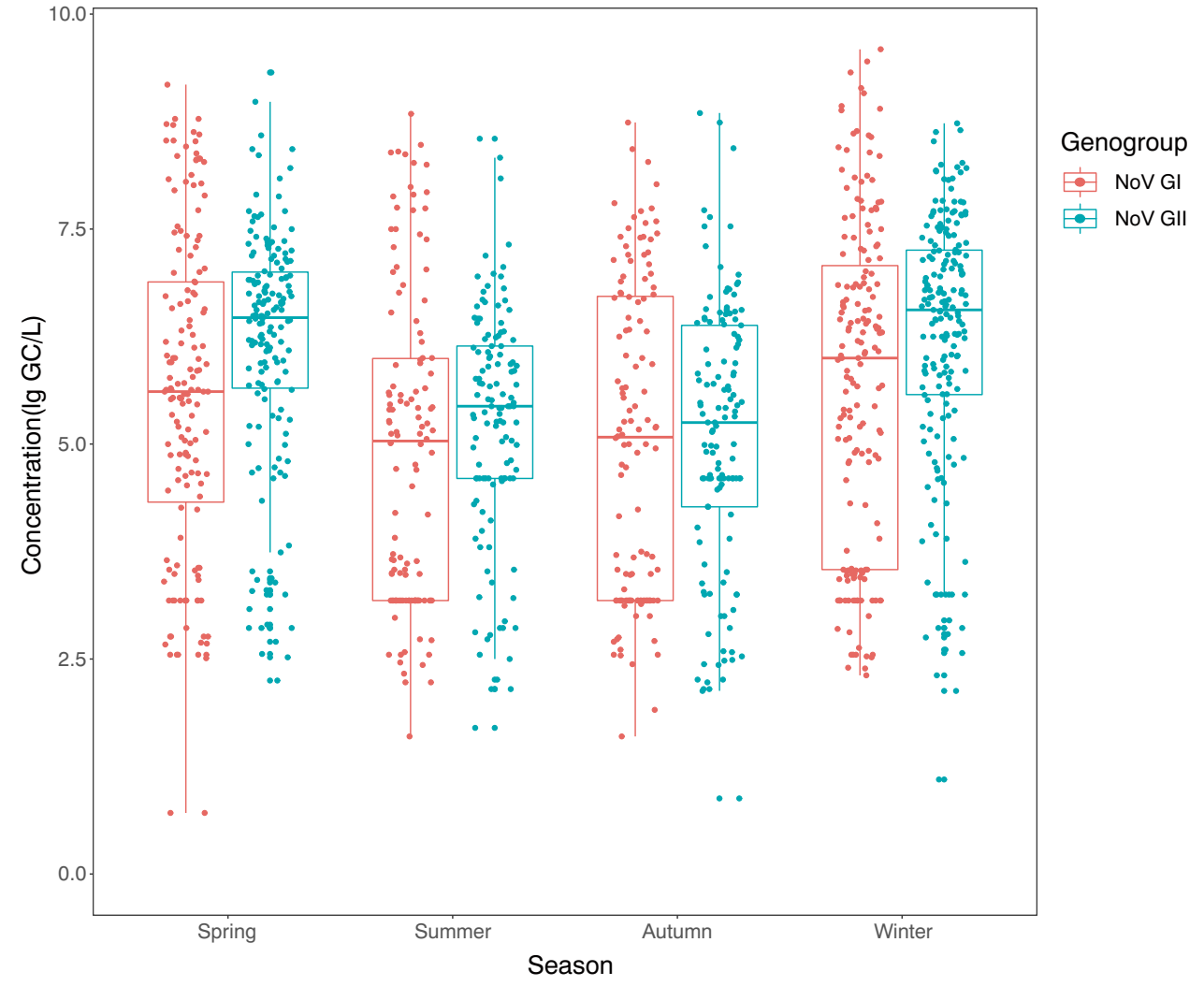




\section{Correlation between NoV detection and population infection}

Seven articles provided detailed monthly data on NoV concentration in wastewater and gastrointestinal infections in local populations. They were divided into different indicators (GI and GII AGE cases, total AGE cases, and NoV outbreaks) and analyzed separately. The percentage of NoV GI infection cases in AGE ranged from 0.00 to $8.00 \%$, and the percentage of GII infection cases ranged from 12.00 to 64.34\%. The number of AGE cases and NoV outbreaks varied widely depending on the size of the study area, but both indicators peaked during the cold season (November to May) (Supplementary Table S5).

Spearman's correlation coefficient was calculated based on raw data from seven studies, and the portion of GII in Carducci et al. (2006) study was not included in the calculations due to severe data deficiencies. The results of the correlation meta-analysis are shown in Fig. 3a, c, and e. Overall, significant positive correlations between the NoV GII concentration in wastewater and GII AGE cases $\left(r_{s}=0.51\right.$, 95\% CI: $\left.0.18-0.74, I^{2}=0 \%\right)$, total AGE cases $\left(r_{s}=0.40,95 \%\right.$ CI: $\left.0.15-0.61, I^{2}=23 \%\right)$, and NoV outbreaks $\left(r_{s}=0.47,95 \%\right.$ CI: $0.30-0.62, I^{2}=0 \%$ ) were founded, while there was no correlation for NoV GI concentration and any of the above indicators. For GII, 32/86/97 data points were available for analysis from six studies. As shown in Fig. 3b, d, and f, these studies did not show consistent statistical significance, but the overall trends were similar and they were also considerably homogeneous: they were conducted in developed regions of Europe and Asia, sampled at relatively similar periods and were all graded as medium to high quality. The homogeneity was also indicated by the fact that $I^{2}$ statistics for heterogeneity tests were all below $25 \%$, i.e., the inferred combined correlation coefficients were reasonable.

Notably, Kazama et al. (2017) conducted a cross-correlation analysis of the concentrations of GI and GII in weekly samples and the number of locally AGE cases. They reported that a significant correlation for GII was observed with a lag of -2 to +6 weeks, and the peak coefficient $(r=0.51)$ was observed at a time lag of 0 weeks. This indicated that changes in GII concentration in wastewater and the increase in the number of reported AGE cases occurred simultaneously. Therefore, the same analysis for other studies that sampled at a frequency of $\leq 2$ weeks was performed. Similarly, peak coefficient time lags of zero, plus, or minus, indicated that the variation in virus concentration coincides with, lags, or exceeds the variation in the number of AGE cases (Kazama et al. 2017). It was observed only in the data of Wang et al. (2020) (sampling per 2 weeks): the concentration of GII in wastewater correlated with the number of total AGE cases at time lags of -6 to +4 weeks, with the peak occurring at a time lag of -2 weeks $(r=0.61)$. No significant correlations were observed in the other eligible studies.

\section{Temporal distribution of the NoV genotype}

Thirty studies analyzed the genotypes of $\mathrm{NoV}$ in wastewater during 2005-2018. Figure 4 shows the prevalence dynamics of the different genotypes at the period with a high sampling frequency (winter 2012 to summer 2017), darker-color blocks represent higher detection rate. There were up to 17 genotypes of NoV with high detection rates and frequency in wastewater. In comparison with the NoV genotype distribution in human AGE infections, a similar trend was observed in wastewater, especially for GII (Supplementary Fig. S1).

For NoV, GI, GI.2, GI.5, and GI.3 were frequently detected in wastewater, and since the summer of 2014, GI.6 was continuously detected at a high and positive rate. For NoV, GII, GII.4, GII.17, GII.2, GII.3, and GII.13 were detected frequently and continuously; particularly, GII.4 was detected at a higher rate before 2015. A notable difference after 2015 was that GI.1, GI.5, GII.4, and GII.6 were no longer detected continuously, but GII.2 was detected more frequently.

\section{Discussion}

WBE has great potential in the field of infectious disease surveillance, where it can serve as one of routine passive screening tools applied in community units to reveal asymptomatic or preclinical states of disease. In response to the COVID-19 pandemic, more precise virus detection and molecular quantification methods were developed and updated by various wastewater monitoring laboratories. Undeniably, undefined methodological criteria are one of the current barriers to interpreting wastewater data when associating virus concentrations in wastewater with disease incidence in contributing populations quantitatively (Greenwald et al. 2021). This systematic review and metaanalysis comprehensively assessed NoV wastewater surveillance studies and quantitatively estimated the correlation between the occurrence of $\mathrm{NoV}$ in wastewater and AGE in the population.

In terms of the quality assessment of including studies, the overall quality of NoV wastewater surveillance studies was not high. And most of them did not consider (or did not state) the recovery rate of the virus and the possible inhibition effect, which may have led to the underestimation of the results. The short sampling period is another feature. Many studies chose one year as the sampling period because this allowed observation of the complete trend of changes in the NoV detection level in different seasons. However, long-term sampling could, in addition, provide a clearer 
a

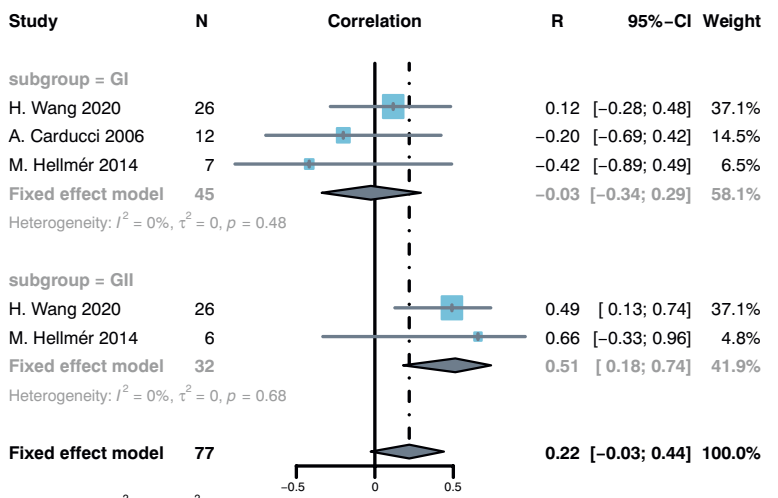

Heterogeneity: $I^{2}=42 \%, \tau^{2}=0.0673, p=0.14$

Test for subgroup differences: $\chi_{1}^{2}=5.28, \mathrm{df}=1(p=0.02)$

C

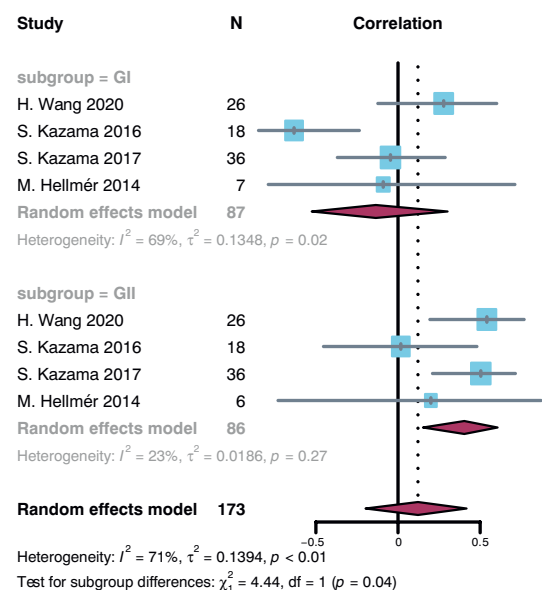

R $95 \%-\mathrm{Cl}$ Weight

$0.28 \quad[-0.12 ; 0.60] \quad 14.7 \%$ $-0.63[-0.85 ;-0.24] 13.1 \%$ $-0.05 \quad[-0.37 ; 0.29] 15.9 \%$ $-0.09[-0.79 ; 0.71] \quad 6.9 \%$ $-0.14[-0.52 ; 0.30] \quad 50.6 \%$

$0.54 \quad[0.19 ; 0.77] \quad 14.7 \%$ $0.02[-0.45 ; 0.48] 13.1 \%$ $0.50 \quad[0.21 ; 0.71] \quad 15.9 \%$ $0.20[-0.73 ; 0.87] \quad 5.7 \%$ $0.40 \quad[0.15 ; 0.61] \quad 49.4 \%$ $0.12[-0.20 ; 0.42] 100.0 \%$ Test for subgroup differences: $\chi_{1}^{2}=4.44, \mathrm{df}=1(p=0.04)$

e

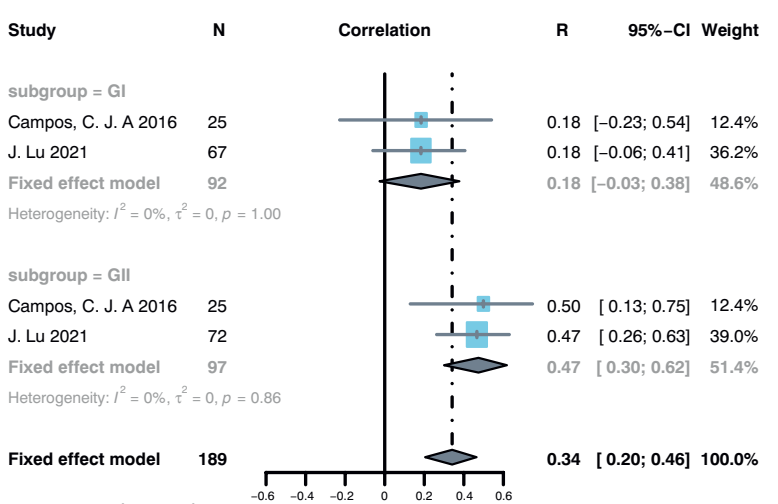

Heterogeneity: $I^{2}=38 \%, \tau^{2}=0.0152, p=0.18$

Test for subgroup differences: $\chi_{1}^{2}=4.81, \mathrm{df}=1(p=0.03)$ b

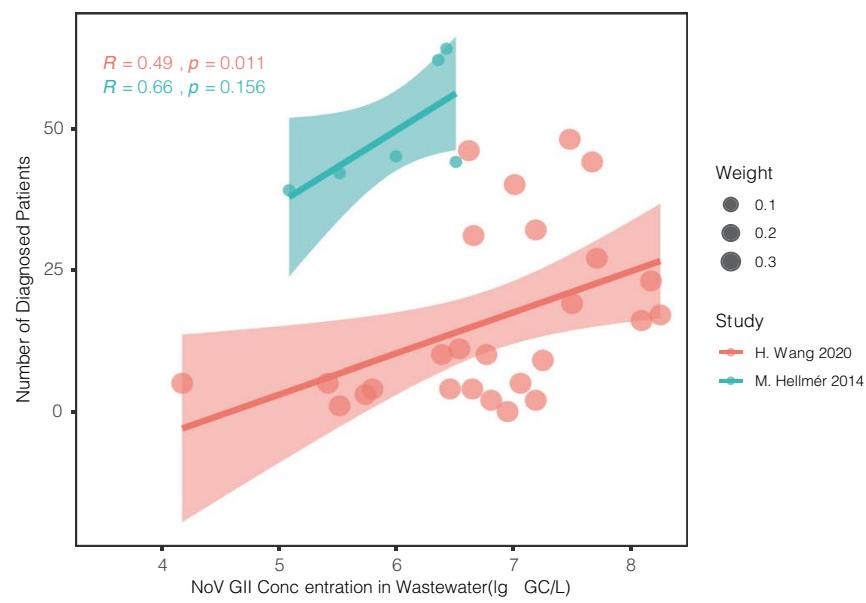

d

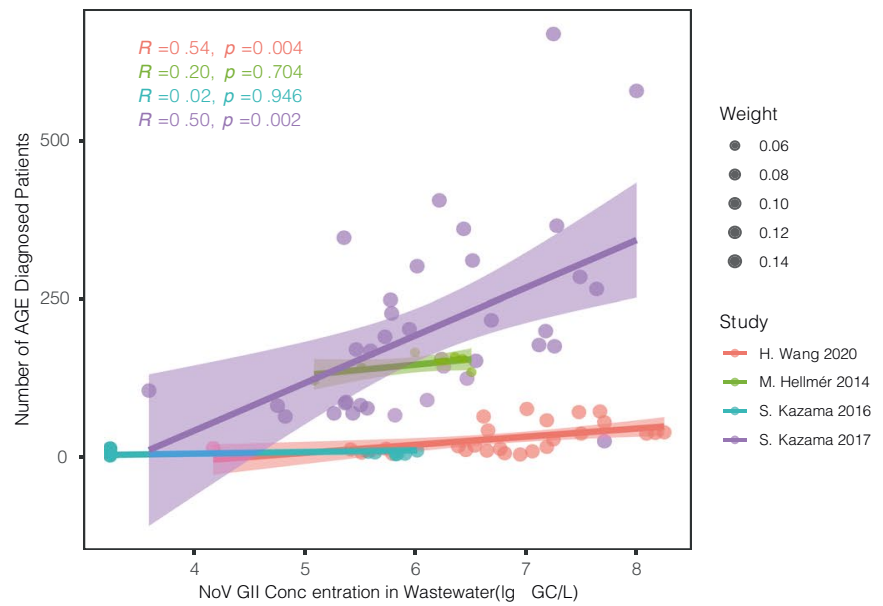

f

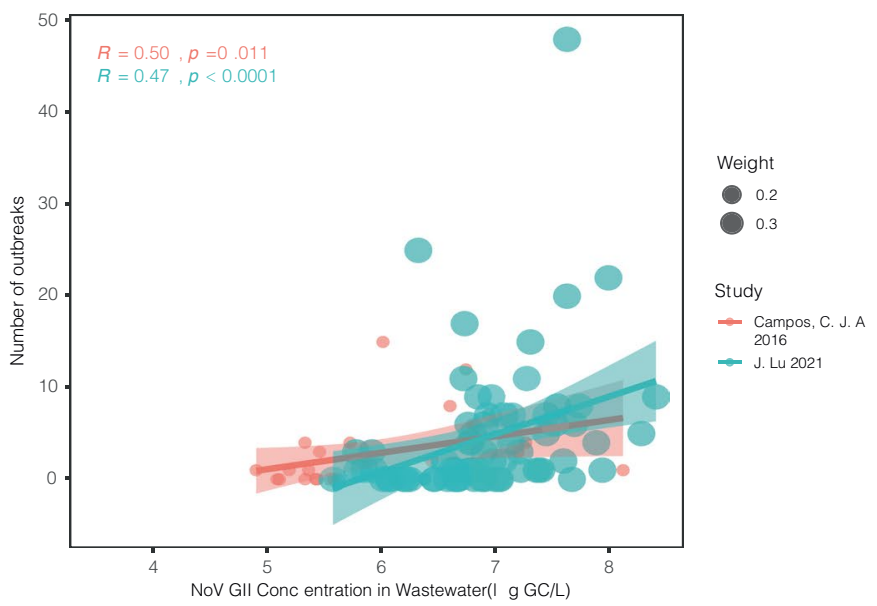


4Fig. 3 Forest plots of correlation between NoV GI and GII detection in wastewater and number of a corresponding genogroups of AGE cases, $\mathbf{c}$ total AGE cases, and $\mathbf{e}$ outbreaks; bubble plots for correlation between NoV GII detection in wastewater and b GII AGE cases, $\mathbf{d}$ total AGE cases, and $\mathbf{f}$ outbreaks in each study. (For the forest plots, of concern are the respective combined results within subgroups (GI \& GII). Heterogeneity exists in the correlation between NoV GI detection in wastewater and number of total AGE cases (c), using the random effects model; for the bubble plots, which showed the trends presented in data points from each study, colors represented different studies and the size of the bubbles was determined by the weights of each study.)

observation of the trends in the individual genotypes of $\mathrm{NoV}$ and the determination of the distribution of local characteristics and dominant genotypes.

The overall detection rate of $\mathrm{NoV}$ in wastewater was $82.10 \%$, suggesting its high prevalence in the human population worldwide. NoV RNA is shed from the feces of infected people and not susceptible to degradation; therefore, NoV transmission constantly circulates between infected human populations and environmental water (Teunis et al. 2015). The results of meta-regression showed that the detection rate of NoV was associated with genogroup and country mortality: NoV GIV was less detected, and studies in high-mortality developing countries reported lower detection rates. NoV GIV is more difficult to detect in environmental, clinical, or bivalve samples, and the mechanisms of its transmission and mutation are still unclear and deserve further exploration (Kremer et al. 2011; La Rosa et al. 2012). The low detection rate of NoV in high-mortality developing countries should not be seen as a promising result; contrarily, it may indicate that bacteria and parasites were the dominant pathogens in water of low-income countries, where they contributed to the major disease burden of gastrointestinal infections, which is also consistent with the findings of previous studies (Ahmed et al. 2014). In our study, there were few studies from highmortality developing countries, and therefore, the inadequate sample size may have led to some estimation error.

This study compared seasonal differences in the concentrations of NoV GI and GII in wastewater. An apparent seasonal pattern for GI and GII was observed, with distinct peaks during winter and spring. This characteristic has also been verified in numerous clinical studies: NoV AGE cases and outbreaks tend to occur in winter or rather the cooler months (Ahmed et al. 2013; Farkas et al. 2018; Greer et al. 2009; van Beek et al. 2018). These findings demonstrated that NoV has greater propagation and persistence in cold environments. Additionally, it may be influenced by other environmental factors such as relative humidity and latitude, as well as demographic characteristics and even infectious disease pandemic events such as the COVID-19 pandemic (Eftim et al. 2017; Oâ Reilly et al. 2021; Shamkhali Chenar and Deng 2017). It is necessary to conduct more exploration and argumentation studies.
The results of the meta-analysis suggested that the concentration of NoV GII in wastewater were positively correlated with indicators reflecting AGE in the population (number of GII AGE cases, total AGE cases, and number of outbreaks). The correlation coefficients ranged from $0.40-0.51$, which suggested changes in GII particles in wastewater can signify the occurrence of AGE. But for GI, no significant correlation was observed. It was impractical to establish a correlation between wastewater NoV detection and clinical cases of GI AGE infection, as GI mostly resulted in mild or asymptomatic infections, and was hard to detect in clinical surveillance. Of the NoV outbreaks, comparing GI and GII horizontally, it can be assumed that more outbreaks were caused by GII, which is consistent with the findings of clinical reports (Matthews et al. 2012; Parikh et al. 2020).

The predicted lead time provides significant evidence to prove the correlation. Kazama et al. (2017) found that the concentration of GII in sewage varied synchronously with the number of local AGE cases. By cross-correlation analysis with the data from Wang et al. (2020) study, the change in the concentration of GII was 2 weeks ahead of the occurrence of local AGE infection cases. A limitation of this result must be noted as the crude sampling frequency did not allow for calculating the lag period more precisely. However, it can still be argued that it further demonstrated the potential correlation.

This study mapped the global NoV diversity trends by bringing together numerous short-term, small-scale studies. At least $17 \mathrm{NoV}$ genotypes were consistently and frequently detected in wastewater. Comparison with the genotype distribution of human AGE cases revealed relatively consistent trends, suggesting that multiple genotypes of NoV GI and GII co-circulation in the population. Several mutations of GII.4, which is the main strain causing the global NoV AGE pandemic, have been reported (Lindesmith et al. 2008; van Beek et al. 2013). Since 2012, GII.4 Sydney 2012 was the most frequently and predominantly detected strain in wastewater. For the molecular epidemiological analysis of $\mathrm{NoV}$ in the last five years, the GII.4 Sydney 2012 variant remains the main strain causing AGE outbreaks in most regions of the world (Cannon et al. 2021; Utsumi et al. 2021; Zhou et al. 2020).

During the winter of 2014 and 2015, several Asian countries reported that GII.17 Kawasaki was the main pathogen causing NoV AGE outbreaks (Chan et al. 2015; de Graaf et al. 2015, Matsushima et al. 2015). In fact, GII.17 was first detected before 2014 in sewage but mostly at low levels (Kazama et al. 2017; Suffredini et al. 2018) suggesting that it circulated in human populations until it became the dominant strain; molecular epidemiological studies of AGE cases in humans have also reported this finding (van Beek et al. 2018). 
Fig. 4 Temporal distribution of NoV genotypes from winter 2012 to summer 2017

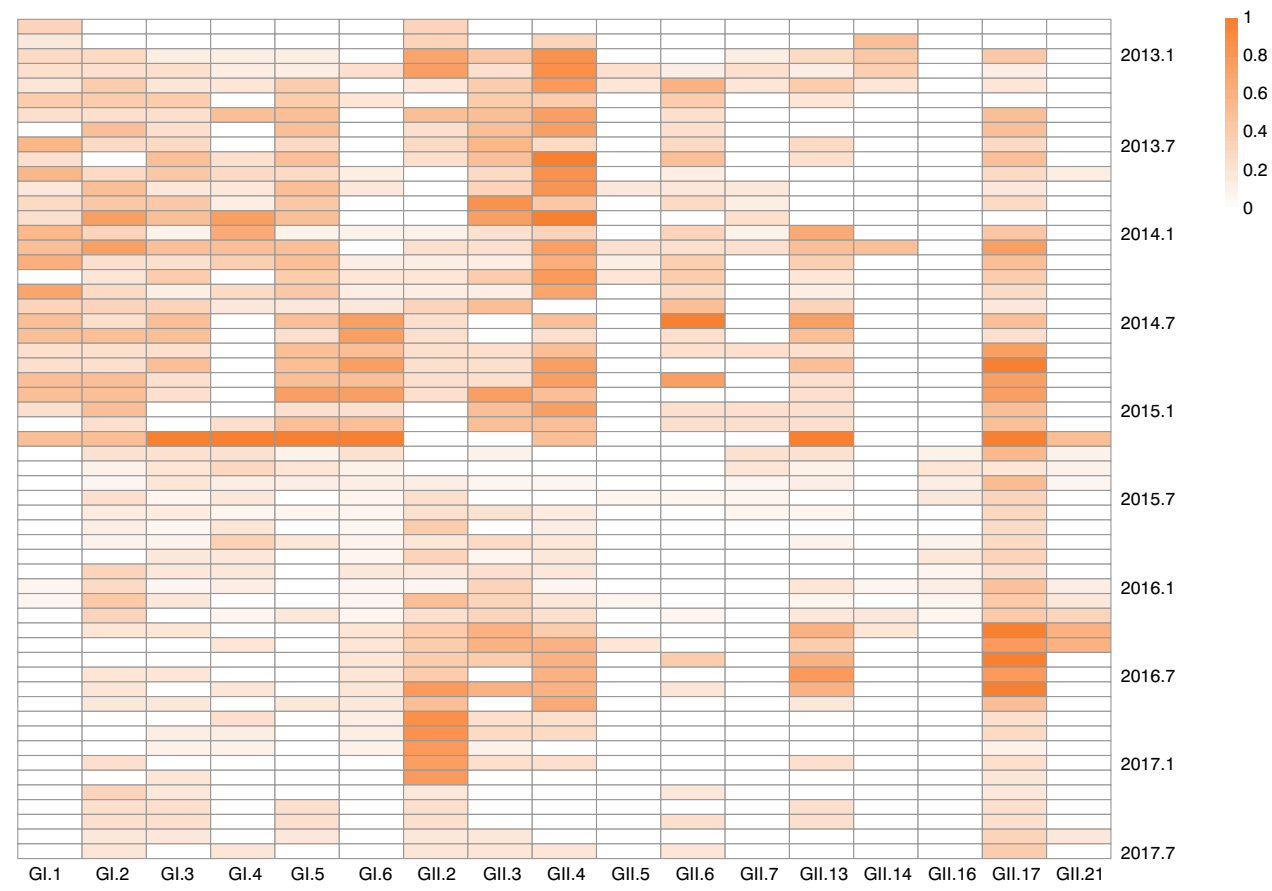

GII.2 was increasingly identified in wastewater surveillance studies after mid-2015. Of note, most articles assessed in this review pointed out that GII.2 predominance stemmed from the recombinant GII.2[P16] (Lu et al. 2021; Lun et al. 2018; Santiso-Bellón et al. 2020). Reports about AGE cases and outbreaks caused by GII.2[P16] have focused on clinical surveillance in various regions during the winter of 2016 and 2017 (Bidalot et al. 2017, Bonura et al. 2021; Li et al. 2018; Medici et al. 2018). The GII.P16 polymerase also paired with some other capsid genotypes, including the predominant strain GII.4 Sydney 2012. The occurrence of GII.2[P16] and GII.4 Sydney 2012[P16] suggested that recombination between such non-closely related sequences may facilitate their adaptation and transmission in the population (van Beek et al. 2018).

Since the emergence of the COVID-19 pandemic, strict social restriction measures in each country have led to a significant reduction in NoV infection (Ahn et al. 2021; Eigner et al. 2021; Lennon et al. 2020). Douglas et al. suggested that the reduction in referred NoV-positive samples and genotyping during the COVID-19 pandemic may have resulted in missing key indicators of NoV strain replacement events (Douglas et al. 2021). Therefore, there is a need to establish a sensitive and effective monitoring system to respond to possible peaks of outbreaks after the removal of restrictions.

This study had limitations. First, because of the insufficient information, we did not consider variables such as sewage sampling method (grab or composite sampling), storage temperature and duration, efficiency of the PCR assay, population size served by WWTP, and local AGE prevalence during the sampling period, which prevented us to explore the heterogeneity of NoV detection rates in a more detailed manner. Second, the use of a value equal to the LOD divided by square root of 2 to replace values reported below the LOD may have led to the overestimation of the NoV concentration in the sewage water. Third, despite relaxing the criteria for our review, there were still too few studies reporting both NoV detection in wastewater and the gastroenteritis infection status in the population, which may result in a loss of partial representation. Furthermore, in these studies, the data reflecting the status of AGE infection included the number of clinical cases and outbreaks, rather than the local incidence or prevalence, which may have led to biased estimates.

\section{Conclusion}

Through the review of previous NoV wastewater monitoring studies, a positive correlation between NoV GII concentration in wastewater and AGE infections was observed, and cross-correlation analysis of partial data indicated that variations in GII concentration were consistent with or ahead of that in the number of AGE cases. The diversity of NoV genotypes in wastewater was also observed, and the dominant strains in the wastewater showed a consistent temporal distribution with that in human AGE cases. Our study demonstrates the potential association of NoV detection in wastewater with AGE infections in the population, and further studies are needed to confirm this conclusion.

Supplementary Information The online version contains supplementary material available at https://doi.org/10.1007/s11356-021-18202-x. 
Acknowledgements We thank all the reviewers for their suggestions.

Author contribution All authors contributed to the study conception and design. Conceptualization: YH, NZ, and HJ; Data curation: $\mathrm{YH}$, SZ, and YY; Methodology: YH, YH, ML, YH, NZ, and HJ; Formal analysis: YH, NS, and LY; Validation: QW and TC; Visualization: $\mathrm{YH}$; Writing — original draft preparation: $\mathrm{YH}, \mathrm{NZ}$, and $\mathrm{HJ}$; Writing—review and editing: $\mathrm{YH}, \mathrm{NZ}$, and $\mathrm{HJ}$; Funding acquisition: $\mathrm{HJ}, \mathrm{NZ}$, and $\mathrm{YH}$; Supervision: HJ. All authors read and approved the final manuscript.

Funding This research was supported by the National Natural Science Foundation of China (81573258; 82003513), the Science Technology Demonstration Project for Emerging Infectious Diseases Control and Prevention (BE2017749), Jiangsu Provincial Six Talent Peak (WSN002), Jiangsu Provincial Key Medical Discipline (ZDXKA2016008), and Postgraduate Practice Innovation Program of Jiangsu Province (SJCX21_0091).

Availability of data and materials The datasets used and analyzed during the current study are available from the corresponding author on reasonable request.

\section{Declarations}

Ethics approval and consent to participate Not applicable.

Consent for publication Not applicable.

Competing interests The authors declare no competing interests.

\section{References}

Ahmed SM, Lopman BA, Levy K (2013) A systematic review and meta-analysis of the global seasonality of norovirus. PLoS One 8:e75922. https://doi.org/10.1371/journal.pone.0075922

Ahmed S, Hall A, Robinson A, Verhoef L, Premkumar P, Parashar U, Koopmans M, Lopman B (2014) Global prevalence of norovirus in cases of gastroenteritis: a systematic review and metaanalysis. Lancet Infect Dis 14:725-730. https://doi.org/10.1016/ s1473-3099(14)70767-4

Ahn SY, Park JY, Lim IS, Chae SA, Yun SW, Lee NM, Kim SY, Choi BS, Yi DY (2021) Changes in the occurrence of gastrointestinal infections after COVID-19 in Korea. J Korean Med Sci 36:e180. https://doi.org/10.3346/jkms.2021.36.e180

Amarasiri M, Kitajima M, Miyamura A, Santos R, Monteiro S, Miura T, Kazama S, Okabe S, Sano D (2018) Reverse transcriptionquantitative PCR assays for genotype-specific detection of human noroviruses in clinical and environmental samples. Int J Hyg Environ Health 221:578-585. https://doi.org/10.1016/j.ijheh.2018.02. 008

Aw TG, Gin KYH (2010) Environmental surveillance and molecular characterization of human enteric viruses in tropical urban wastewaters. J Appl Microbiol 109:716-730. https://doi.org/10.1111/j. 1365-2672.2010.04701.x

Bidalot M, Théry L, Kaplon J, De Rougemont A, Ambert-Balay K (2017) Emergence of new recombinant noroviruses GII.p16-GII.4 and GII.p16-GII.2, France, winter 2016 to 2017. Euro Surveill 22. https://doi.org/10.2807/1560-7917.Es.2017.22.15.30508

Bonura F, Urone N, Bonura C, Mangiaracina L, Filizzolo C, Sciortino G, Sanfilippo GL, Martella V, Giammanco GM, De Grazia S (2021) Recombinant GII.P16 genotype challenges RT-PCR-based typing in region A of norovirus genome. J Infect 83:69-75. https:// doi.org/10.1016/j.jinf.2021.04.015

Campos CJA, Avant J, Lowther J, Till D, Lees DN (2016) Human norovirus in untreated sewage and effluents from primary, secondary and tertiary treatment processes. Water Res 103:224-232. https:// doi.org/10.1016/j.watres.2016.07.045

Cannon JL, Barclay L, Collins NR, Wikswo ME, Castro CJ, Magaña LC, Gregoricus N, Marine RL, Chhabra P, Vinjé J (2017) Genetic and epidemiologic trends of norovirus outbreaks in the United States from 2013 to 2016 demonstrated emergence of novel GII.4 recombinant viruses. J Clin Microbiol 55:2208-2221. https://doi. org/10.1128/jcm.00455-17

Cannon JL et al (2021) Global trends in norovirus genotype distribution among children with acute gastroenteritis. Emerg Infect Dis 27:1438-1445. https://doi.org/10.3201/eid2705.204756

Carducci A, Verani M, Battistini R, Pizzi F, Rovini E, Andreoli E, Casini B (2006) Epidemiological surveillance of human enteric viruses by monitoring of differnet environmental matrices. 239-244

Chan MC, Lee N, Hung TN, Kwok K, Cheung K, Tin EK, Lai RW, Nelson EA, Leung TF, Chan PK (2015) Rapid emergence and predominance of a broadly recognizing and fast-evolving norovirus GII.17 variant in late 2014. Nat Commun 6:10061. https://doi.org/ 10.1038/ncomms 10061

Chavarria-Miró G, Anfruns-Estrada E, Martínez-Velázquez A, Vázquez-Portero M, Guix S, Paraira M, Galofré B, Sánchez G, Pintó RM, Bosch A (2021) Time evolution of severe acute respiratory syndrome Coronavirus 2 (SARS-CoV-2) in wastewater during the first pandemic wave of COVID-19 in the metropolitan area of Barcelona, Spain. Appl Environ Microbiol 87. https://doi. org/10.1128/aem.02750-20

Chhabra P, de Graaf M, Parra GI, Chan MC, Green K, Martella V, Wang Q, White PA, Katayama K, Vennema H, Koopmans MPG, Vinjé J (2019) Updated classification of norovirus genogroups and genotypes. J Gen Virol 100:1393-1406. https://doi.org/10. 1099/jgv.0.001318

Da Silva AK, Le Saux JC, Parnaudeau S, Pommepuy M, Elimelech M, Le Guyader FS (2007) Evaluation of removal of noroviruses during wastewater treatment, using real-time reverse transcriptionPCR: Different behaviors of genogroups I and II. Appl Environ Microbiol 73:7891-7897. https://doi.org/10.1128/AEM.01428-07

Daughton CG (2020) Wastewater surveillance for population-wide Covid-19: The present and future. Sci Total Environ 736:139631. https://doi.org/10.1016/j.scitotenv.2020.139631

de Graaf M, van Beek J, Vennema H, Podkolzin AT, Hewitt J, Bucardo F, Templeton K, Mans J, Nordgren J, Reuter G, Lynch M, Rasmussen LD, Iritani N, Chan MC, Martella V, Ambert-Balay K, Vinjé J, White PA, Koopmans MP (2015) Emergence of a novel GII.17 norovirus - end of the GII.4 era? Euro Surveill 20. https:// doi.org/10.2807/1560-7917.es2015.20.26.21178

de Wit MA, Koopmans MP, Kortbeek LM, Wannet WJ, Vinjé J, van Leusden F, Bartelds AI, van Duynhoven YT (2001) Sensor, a population-based cohort study on gastroenteritis in the Netherlands: incidence and etiology. Am J Epidemiol 154:666-674. https://doi. org/10.1093/aje/154.7.666

Douglas A, Sandmann FG, Allen DJ, Celma CC, Beard S, Larkin L (2021) Impact of COVID-19 on national surveillance of norovirus in England and potential risk of increased disease activity in 2021. J Hosp Infect 112:124-126. https://doi.org/10.1016/j.jhin.2021.03.006

Eftim SE, Hong T, Soller J, Boehm A, Warren I, Ichida A, Nappier SP (2017) Occurrence of norovirus in raw sewage - a systematic literature review and meta-analysis. Water Res 111:366-374. https:// doi.org/10.1016/j.watres.2017.01.017

Eigner U, Verstraeten T, Weil J (2021) Decrease in norovirus infections in Germany following COVID-19 containment measures. J Infect 82:276-316. https://doi.org/10.1016/j.jinf.2021.02.012 
Farkas K, Marshall M, Cooper D, McDonald JE, Malham SK, Peters DE, Maloney JD, Jones DL (2018) Seasonal and diurnal surveillance of treated and untreated wastewater for human enteric viruses. Environ Sci Pollut Res Int 25:33391-33401. https://doi. org/10.1007/s11356-018-3261-y

Fioretti JM, Fumian TM, Rocha MS, dos Santos IAL, Carvalho-Costa FA, de Assis MR, Rodrigues JS, Leite JPG, Miagostovich MP (2018) Surveillance of Noroviruses in Rio De Janeiro, Brazil: Occurrence of New GIV Genotype in Clinical and Wastewater Samples. Food Environ Virol 10.https://doi.org/10.1007/ s12560-017-9308-2

Fumian TM, Fioretti JM, Lun JH, dos Santos IAL, White PA, Miagostovich MP (2019) Detection of norovirus epidemic genotypes in raw sewage using next generation sequencing. Environ Int 123:282-291. https://doi.org/10.1016/j.envint.2018.11.054

Green KY (2018) Norovirus surveillance comes of age: the impact of NoroNet. Lancet Infect Dis 18:482-483. https://doi.org/10.1016/ s1473-3099(18)30062-8

Greenwald HD et al (2021) Tools for interpretation of wastewater SARS-CoV-2 temporal and spatial trends demonstrated with data collected in the San Francisco Bay area. Water Res X 12:100111. https://doi.org/10.1016/j.wroa.2021.100111

Greer AL, Drews SJ, Fisman DN (2009) Why "Winter" vomiting disease? seasonality, hydrology, and norovirus epidemiology in Toronto, Canada. EcoHealth 6:192-199. https://doi.org/10.1007/ s10393-009-0247-8

Grøndahl-Rosado RC, Yarovitsyna E, Trettenes E, Myrmel M, Robertson LJ (2014) A One Year Study on the Concentrations of Norovirus and Enteric Adenoviruses in Wastewater and A Surface Drinking Water Source in Norway. Food Environ Virol 6:232245. https://doi.org/10.1007/s12560-014-9161-5

Gurung K, Ncibi MC, Sillanpää M (2017) Assessing membrane fouling and the performance of pilot-scale membrane bioreactor (MBR) to treat real municipal wastewater during winter season in Nordic regions. Sci Total Environ 579:1289-1297. https://doi.org/10. 1016/j.scitotenv.2016.11.122

Han TH, Kim SC, Kim ST, Chung CH, Chung JY (2014) Detection of norovirus genogroup IV, klassevirus, and pepper mild mottle virus in sewage samples in South Korea. Adv Virol 159:457-463. https://doi.org/10.1007/s00705-013-1848-7

Haramoto E, Yamada K, Nishida K (2011) Prevalence of protozoa, viruses, coliphages and indicator bacteria in groundwater and river water in the Kathmandu Valley, Nepal. Trans R Soc Trop Med Hyg 105:711-716. https://doi.org/10.1016/j.trstmh.2011.08.004

Hassine-Zaafrane M, Sdiri-Loulizi K, Kaplon J, Salem IB, Pothier P, Aouni M, Ambert-Balay K (2014) Molecular Detection of human Noroviruses in Influent and Effluent Samples From Two Biological Sewage Treatment Plants in the Region of Monastir, Tunisia. Food Environm Virol 6:125-131. https://doi.org/10.1007/ s12560-014-9147-3

Hellmér M, Paxéus N, Magnius L, Enache L, Arnholm B, Johansson A, Bergström T, Norder H (2014) Detection of pathogenic viruses in sewage provided early warnings of hepatitis A virus and norovirus outbreaks. Appl Environ Microbiol 80:6771-6781. https://doi.org/ 10.1128/AEM.01981-14

Ibrahim C, Hammami S, Khelifi N, Pothier P, Hassen A (2020) The Effectiveness of Activated Sludge Procedure and UV-C(254) in Norovirus Inactivation in a Tunisian Industrial Wastewater Treatment Plant. Food Environ Virol 12:250-259. https://doi.org/10. 1007/s12560-020-09434-0

Jin M, Wu S, Kong X, Xie H, Fu J, He Y, Feng W, Liu N, Li J, Rainey JJ, Hall AJ, Vinjé J, Duan Z (2020) Norovirus outbreak surveillance, China, 2016-2018. Emerg Infect Dis 26:437-445. https:// doi.org/10.3201/eid2603.191183

Kamel AH, Ali MA, El-Nady HG, Aho S, Pothier P, Belliot G (2010) Evidence of the co-circulation of enteric viruses in sewage and in the population of Greater Cairo. J Appl Microbiol 108:1620 1629. https://doi.org/10.1111/j.1365-2672.2009.04562.x

Kauppinen A, Martikainen K, Matikka V, Veijalainen AM, Pitkänen T, Heinonen-Tanski H, Miettinen IT (2014) Sand filters for removal of microbes and nutrients from wastewater during a one-year pilot study in a cold temperate climate. J Environ Manag 133:206-213. https://doi.org/10.1016/j.jenvman.2013.12.008

Kazama S, Masago Y, Tohma K, Souma N, Imagawa T, Suzuki A, Liu X, Saito M, Oshitani H, Omura T (2016) Temporal dynamics of norovirus determined through monitoring of municipal wastewater by pyrosequencing and virological surveillance of gastroenteritis cases. Water Res 92:244-253. https://doi.org/10.1016/j. watres.2015.10.024

Kazama S, Miura T, Masago Y, Konta Y, Tohma K, Manaka T, Liu X, Nakayama D, Tanno T, Saito M, Oshitani H, Omura T (2017) Environmental Surveillance of Norovirus Genogroups I and II for Sensitive Detection of Epidemic Variants. Appl Environ Microbiol 83. https://doi.org/10.1128/AEM.03406-16

Kitajima M, Haramoto E, Phanuwan C, Katayama H, Furumai H (2012) Molecular detection and genotyping of human noroviruses in influent and effluent water at a wastewater treatment plant in Japan. J Appl Microbiol 112:605-613. https://doi.org/10.1111/j. 1365-2672.2012.05231.x

Kobayashi N, Oshiki M, Ito T, Segawa T, Hatamoto M, Kato T, Yamaguchi T, Kubota K, Takahashi M, Iguchi A, Tagawa T, Okubo T, Uemura S, Harada H, Motoyama T, Araki N, Sano D (2017) Removal of human pathogenic viruses in a down-flow hanging sponge (DHS) reactor treating municipal wastewater and health risks associated with utilization of the effluent for agricultural irrigation. Water Res 110:389-398. https://doi.org/10.1016/j. watres.2016.10.054

Kremer JR, Langlet J, Skraber S, Weicherding P, Weber B, Cauchie HM, de Landtsheer S, Even J, Muller CP, Hoffmann L, Mossong J (2011) Genetic diversity of noroviruses from outbreaks, sporadic cases and wastewater in Luxembourg 2008-2009. Clin Microbiol Infect 17:1173-1176. https://doi.org/10.1111/j.1469-0691.2010.03407.x

La Rosa G, Pourshaban M, Iaconelli M, Muscillo M (2008) Detection of genogroup IV noroviruses in environmental and clinical samples and partial sequencing through rapid amplification of cDNA ends. Adv Virol 153:2077-2083. https://doi.org/10.1007/ s00705-008-0241-4

La Rosa G, Iaconelli M, Pourshaban M, Muscillo M (2010) Detection and molecular characterization of noroviruses from five sewage treatment plants in central Italy. Water Res 44:1777-1784. https:// doi.org/10.1016/j.watres.2009.11.055

La Rosa G, Fratini M, SpuriVennarucci V, Guercio A, Purpari G, Muscillo M (2012) GIV noroviruses and other enteric viruses in bivalves: a preliminary study. New Microbiol 35:27-34

Lennon RP, Griffin C, Miller EL, Dong H, Rabago D, Zgierska AE (2020) Norovirus infections drop $49 \%$ in the United States with strict COVID-19 public health interventions. Acta Med Acad 49:278-280. https://doi.org/10.5644/ama2006-124.317

Li J, Zhang T, Cai K, Jiang Y, Guan X, Zhan J, Zou W, Yang Z, Xing X, Wu Y, Song Y, Yu X, Xu J (2018) Temporal evolutionary analysis of re-emerging recombinant GII.P16_GII.2 norovirus with acute gastroenteritis in patients from Hubei Province of China, 2017. Virus Res 249:99-109. https://doi.org/10.1016/j.virusres. 2018.03.016

Lin X, Zou R, Liu Y, Ji F, Tao Z, Xu A (2021) Continuous detection of norovirus and astrovirus in wastewater in a coastal city of China in 2014-2016. Lett Appl Microbiol. https://doi.org/10. 1111/lam.13530

Lindesmith LC, Donaldson EF, Lobue AD, Cannon JL, Zheng DP, Vinje J, Baric RS (2008) Mechanisms of GII4 norovirus persistence in human populations. PLoS Med 5:e31. https://doi.org/ 10.1371/journal.pmed.0050031 
Lopman BA, Steele D, Kirkwood CD, Parashar UD (2016) The vast and varied global burden of norovirus: prospects for prevention and control. PLoS Med 13:e1001999. https://doi.org/10.1371/ journal.pmed.1001999

Lu J et al (2021) Capturing noroviruses circulating in the population: sewage surveillance in Guangdong, China (2013-2018). Water Res 196:116990. https://doi.org/10.1016/j.watres.2021.116990

Lun JH, Hewitt J, Sitabkhan A, Eden JS, Enosi Tuipulotu D, Netzler NE, Morrell L, Merif J, Jones R, Huang B, Warrilow D, Ressler KA, Ferson MJ, Dwyer DE, Kok J, Rawlinson WD, Deere D, Crosbie ND, White PA (2018) Emerging recombinant noroviruses identified by clinical and waste water screening article. Emerg Microbes Infect 7. https://doi.org/10.1038/s41426-018-0047-8

Mabasa VV, Meno KD, Taylor MB, Mans J (2018) Environmental Surveillance for Noroviruses in Selected South African Wastewaters 2015-2016: Emergence of the Novel GII.17. Food Environ Virol 10:16-28. https://doi.org/10.1007/s12560-017-9316-2

Masago Y, Konta Y, Kazama S, Inaba M, Imagawa T, Tohma K, Saito M, Suzuki A, Oshitani H, Omura T (2016) Comparative evaluation of real-time PCR methods for human noroviruses in wastewater and human stool. PLoS One 11. https://doi.org/10.1371/ journal.pone. 0160825

Masclaux FG, Hotz P, Friedli D, Savova-Bianchi D, Oppliger A (2013) High occurrence of hepatitis $\mathrm{E}$ virus in samples from wastewater treatment plants in Switzerland and comparison with other enteric viruses. Water Res 47:5101-5109. https://doi.org/10. 1016/j.watres.2013.05.050

Matsushima Y, Ishikawa M, Shimizu T, Komane A, Kasuo S, Shinohara M, Nagasawa K, Kimura H, Ryo A, Okabe N, Haga K, Doan YH, Katayama K, Shimizu H (2015) Genetic analyses of GII.17 norovirus strains in diarrheal disease outbreaks from December 2014 to March 2015 in Japan reveal a novel polymerase sequence and amino acid substitutions in the capsid region. Euro Surveill 20. https://doi.org/10.2807/1560-7917.es2015.20.26.21173

Matthews JE, Dickey BW, Miller RD, Felzer JR, Dawson BP, Lee AS, Rocks JJ, Kiel J, Montes JS, Moe CL, Eisenberg JN, Leon JS (2012) The epidemiology of published norovirus outbreaks: a review of risk factors associated with attack rate and genogroup. Epidemiol Infect 140:1161-1172. https://doi.org/10.1017/s0950 268812000234

McCall C, Wu H, Miyani B, Xagoraraki I (2020) Identification of multiple potential viral diseases in a large urban center using wastewater surveillance. Water Res 184. https://doi.org/10.1016/j.watres. 2020.116160

Medema G, Heijnen L, Elsinga G, Italiaander R, Brouwer A (2020) Presence of SARS-Coronavirus-2 RNA in sewage and correlation with reported COVID-19 prevalence in the early stage of the epidemic in the Netherlands. Environ Sci Technol Lett 7:511-516. https://doi.org/10.1021/acs.estlett.0c00357

Medici MC, Tummolo F, Martella V, De Conto F, Arcangeletti MC, Pinardi F, Ferraglia F, Chezzi C, Calderaro A (2018) Emergence of novel recombinant GII.P16_GII.2 and GII. P16_GII.4 Sydney 2012 norovirus strains in Italy, winter 2016/2017. New Microbiol 41:71-72

Miura T, Okabe S, Nakahara Y, Sano D (2015) Removal properties of human enteric viruses in a pilot-scale membrane bioreactor (MBR) process. Water Res 75:282-291. https://doi.org/10.1016/j. watres.2015.02.046

Montazeri N, Goettert D, Achberger EC, Johnson CN, Prinyawiwatkul W, Janes ME (2015) Pathogenic Enteric Viruses and Microbial Indicators during Secondary Treatment of Municipal Wastewater. Appl Environ Microbiol 81:6436-6445. https://doi.org/10.1128/ AEM.01218-15

Muscillo M, Fratini M, Graffeo R, Sanguinetti M, Martella V, Green KY, Della Libera S, La Rosa G (2013) GIV Noroviruses in Wastewaters and in Stool Specimens from Hospitalized
Patients. Food Environ Virol 5:194-202. https://doi.org/10.1007/ s12560-013-9121-5

Netzler NE, EnosiTuipulotu D, White PA (2019) Norovirus antivirals: where are we now? Med Res Rev 39:860-886. https://doi.org/10. $1002 /$ med.21545

Ngazoa ES, Fliss I, Jean J (2008) Quantitative study of persistence of human norovirus genome in water using TaqMan real-time RTPCR. J Appl Microbiol 104:707-715. https://doi.org/10.1111/j. 1365-2672.2007.03597.x

Nordgren J, Svensson L (2019) Genetic susceptibility to human norovirus infection: an update. Viruses 11. https://doi.org/10.3390/ v11030226

Oâ Reilly K, Sandman F, Allen D, Jarvis CI, Gimma A, Douglas A, Larkin L, Wong KL, Baguelin M, Baric RS, Lindesmith LC, Goldstein RA, Breuer J, Edmunds WJ (2021) Predicted norovirus resurgence in 2021-2022 due to the relaxation of nonpharmaceutical interventions associated with COVID-19 restrictions in England: a mathematical modelling study. medRxiv. https://doi. org/10.1101/2021.07.09.21260277

O'Brien E, Xagoraraki I (2019) A water-focused one-health approach for early detection and prevention of viral outbreaks. One Health 7:100094. https://doi.org/10.1016/j.onehlt.2019.100094

Parikh MP, Vandekar S, Moore C, Thomas L, Britt N, Piya B, Stewart LS, Batarseh E, Hamdan L, Cavallo SJ, Swing AM, Garman KN, Constantine-Renna L, Chappell J, Payne DC, Vinjé J, Hall AJ, Dunn JR, Halasa N (2020) Temporal and genotypic associations of sporadic norovirus gastroenteritis and reported norovirus outbreaks in Middle Tennessee, 2012-2016. Clin Infect Dis 71:2398-2404. https://doi.org/10.1093/cid/ciz1106

Peccia J, Zulli A, Brackney DE, Grubaugh ND, Kaplan EH, CasanovasMassana A, Ko AI, Malik AA, Wang D, Wang M, Warren JL, Weinberger DM, Arnold W, Omer SB (2020) Measurement of SARSCoV-2 RNA inwastewater tracks community infection dynamics. Nat Biotechnol 38:1164-1167. https://doi.org/10.1038/s41587-020-0684-Z

Pérez-Sautu U, Sano D, Guix S, Kasimir G, Pintó RM, Bosch A (2012) Human norovirus occurrence and diversity in the Llobregat river catchment, Spain. Environ Microbiol 14:494-502. https://doi.org/ 10.1111/j.1462-2920.2011.02642.x

Prado T, Silva DM, Guilayn WC, Rose TL, Gaspar AMC, Miagostovich MP (2011) Quantification and molecular characterization of enteric viruses detected in effluents from two hospital wastewater treatment plants. Water Res 45:1287-1297. https://doi.org/ 10.1016/j.watres.2010.10.012

Prado T, de Castro BA, Barbosa MRF, Garcia SC, Moreno LZ, Sato MIZ (2019) Noroviruses in raw sewage, secondary effluents and reclaimed water produced by sand-anthracite filters and membrane bioreactor/reverse osmosis system. Sci Total Environ 646:427437. https://doi.org/10.1016/j.scitotenv.2018.07.301

Quee FA, de Hoog MLA, Schuurman R, Bruijning-Verhagen P (2020) Community burden and transmission of acute gastroenteritis caused by norovirus and rotavirus in the Netherlands (RotaFam): a prospective household-based cohort study. Lancet Infect Dis 20:598-606. https://doi.org/10.1016/s1473-3099(20)30058-x

Santiso-Bellón C, Randazzo W, Pérez-Cataluña A, Vila-Vicent S, Gozalbo-Rovira R, Muñoz C, Buesa J, Sanchez G, Rodríguez Díaz J (2020) Epidemiological surveillance of norovirus and rotavirus in sewage (2016-2017) in Valencia (Spain). Microorganisms 8. https://doi.org/10.3390/microorganisms8030458

Sein C (2013) Evaluating surveillance indicators supporting the global polio eradication initiative, 2011-2012. Morb Mortal Wkly Rep 62:270-274

ShamkhaliChenar S, Deng Z (2017) Environmental indicators for human norovirus outbreaks. Int J Environ Health Res 27:40-51. https://doi.org/10.1080/09603123.2016.1257705

Sima LC, Schaeffer J, Le Saux JC, Parnaudeau S, Elimelech M, Le Guyader FS (2011) Calicivirus removal in a membrane bioreactor 
wastewater treatment plant. Appl Environ Microbiol 77:51705177. https://doi.org/10.1128/AEM.00583-11

Skraber S, Langlet J, Kremer JR, Mossong J, De Landtsheer S, Even J, Muller CP, Hoffmann L, Cauchie HM (2011) Concentration and diversity of noroviruses detected in Luxembourg wastewaters in 2008-2009. Appl Environ Microbiol 77:5566-5568. https://doi. org/10.1128/AEM.00632-11

Suffredini E, Iaconelli M, Equestre M, Valdazo-González B, Ciccaglione AR, Marcantonio C, Della Libera S, Bignami F, La Rosa G (2018) Genetic diversity among genogroup II noroviruses and progressive emergence of GII.17 in wastewaters in Italy (2011-2016) revealed by next-generation and Sanger sequencing. Food Environ Virol 10:141-150. https://doi.org/10.1007/s12560-017-9328-y

Tao Z, Xu M, Lin X, Wang H, Song L, Wang S, Zhou N, Zhang D, Xu A (2015) Environmental Surveillance of Genogroup I and II Noroviruses in Shandong Province, China in 2013. Sci Rep 5:17444. https://doi.org/10.1038/srep17444

Teixeira DM, Hernandez JM, Silva LD, Oliveira DS, Spada PKP, Gurjão TCM, Mascarenhas JDAP, Linhares AC, Morais LLCS, Gabbay YB (2016) Occurrence of Norovirus GIV in Environmental Water Samples from Belém City, Amazon Region, Brazil. Food Environ Virol 8:101-104. https://doi.org/10.1007/ s12560-015-9220-6

Teixeira DM, De Pontes Spada PK, De Sá Morais LLC, Fumian TM, De Lima ICG, De Souza OD, Da Silva BR, Gurjão TCM, De Sousa MS, Mascarenhas JDP, Gabbay YB (2017) Norovirus genogroups I and II in environmental water samples from Belém city, Northern Brazil. J Water Health 15:163-174. https://doi.org/10. 2166/wh.2016.275

Teunis PF, Sukhrie FH, Vennema H, Bogerman J, Beersma MF, Koopmans MP (2015) Shedding of norovirus in symptomatic and asymptomatic infections. Epidemiol Infect 143:1710-1717. https://doi.org/10.1017/s095026881400274x

Utsumi T et al (2021) Molecular epidemiology and genetic diversity of norovirus infection in children hospitalized with acute gastroenteritis in East Java, Indonesia in 2015-2019. Infect Genet Evol 88:104703. https://doi.org/10.1016/j.meegid.2020.104703

van Beek J, Ambert-Balay K, Botteldoorn N, Eden JS, Fonager J, Hewitt J, Iritani N, Kroneman A, Vennema H, Vinjé J, White PA, Koopmans M (2013) Indications for worldwide increased norovirus activity associated with emergence of a new variant of genotype II.4, late 2012. Euro Surveill 18:8-9

van Beek J et al (2018) Molecular surveillance of norovirus, 2005-16: an epidemiological analysis of data collected from the NoroNet network. Lancet Infect Dis 18:545-553. https://doi.org/10.1016/ S1473-3099(18)30059-8
Victoria M, Guimarães FR, Fumian TM, Ferreira FFM, Vieira CB, Leite JPG, Miagostovich MP, Shubo T (2010) One year monitoring of norovirus in a sewage treatment plant in Rio de Janeiro, Brazil. J Water Health 8:158-165. https://doi.org/10.2166/wh. 2009.012

Victoria M, Tort LFL, Lizasoain A, García M, Castells M, Berois M, Divizia M, Leite JPG, Miagostovich MP, Cristina J, Colina R (2016) Norovirus molecular detection in Uruguayan sewage samples reveals a high genetic diversity and GII.4 variant replacement along time. J Appl Microbiol 120:1427-1435. https://doi.org/10. 1111/jam.13058

Wang H, Neyvaldt J, Enache L, Sikora P, Mattsson A, Johansson A, Lindh M, Bergstedt O, Norder H (2020) Variations among viruses in influent water and effluent water at a wastewater plant over one year as assessed by quantitative PCR and metagenomics. Appl Environ Microbiol 86. https://doi.org/10.1128/AEM.02073-20

Weidhaas J, Aanderud ZT, Roper DK, VanDerslice J, Gaddis EB, Ostermiller J, Hoffman K, Jamal R, Heck P, Zhang Y, Torgersen K, Vander Laan J, LaCross N (2021) Correlation of SARSCoV-2 RNA in wastewater with COVID-19 disease burden in sewersheds. Sci Total Environ 775. https://doi.org/10.1016/j.scito tenv.2021.145790

World Health Organization. (2003a) The world health report 2003: shaping the future. https://apps.who.int/iris/handle/10665/42789. Accessed 17 August 2021

World Health Organization. (2003b) Guidelines for environmental surveillance of poliovirus circulation. http://www.who.int/vaccinesdocuments/DoxGen/H5-Surv.htm. Accessed 18 November 2021

Wurtzer S, Marechal V, Mouchel JM, Maday Y, Teyssou R, Richard E, Almayrac JL, Moulin L (2020) Evaluation of lockdown effect on SARS-CoV-2 dynamics through viral genome quantification in waste water, Greater Paris, France, 5 March to 23 April 2020. Euro Surveill 25. https://doi.org/10.2807/1560-7917.Es.2020.25. 50.2000776

Zhou N, Lin X, Wang S, Tao Z, Xiong P, Wang H, Liu Y, Song Y, Xu A (2016) Molecular epidemiology of GI and GII noroviruses in sewage: 1-year surveillance in eastern China. J Appl Microbiol 121:1172-1179. https://doi.org/10.1111/jam.13218

Zhou H, Wang S, von Seidlein L, Wang X (2020) The epidemiology of norovirus gastroenteritis in China: disease burden and distribution of genotypes. Front Med 14:1-7. https://doi.org/10.1007/ s11684-019-0733-5

Publisher's note Springer Nature remains neutral with regard to jurisdictional claims in published maps and institutional affiliations. 